\title{
The Use Of Problem Solving Method To Improve The Result Of Mathematics Learning About Length Unit
}

\section{Diah Putri Lestari}

Universitas Sebelas Maret

putrilestaridiah88@gmail.com

\section{Article History}

received 30/4/2021

\begin{abstract}
Ditulis dalam Bahasa Inggris dan Indonesia, maksimal 150 kata, font Arial 10pt, spasi 1. Abstrak menguraikan latar belakang, tujuan, metode penelitian (jika penelitian), hasil kajian atau penelitian, dan simpulanThe purpose of this study is to: find out the use of problem solving methods can improve learning outcomes of mathematics about units of length in class II SD Negeri 5 Panjer Academic Year 2020/2021. This research is a CAR that is planned and carried out by the researchers themselves in two cycles, each cycle consisting of planning, implementation, observation, and reflection. In the first cycle of the first meeting with the percentage of students who have not completed $30.00 \%$ and completed $70.00 \%$. The first cycle of the second meeting is with the percentage of students who have not completed $15,00 \%$ and completed $85 \%$. The second cycle of the first meeting with the percentage of students who have not completed $25.00 \%$ and completed $75.00 \%$. In the second cycle of the second meeting, the problem-solving method continued to increase with the percentage of students not completing $10.00 \%$ and completing $90.00 \%$. The conclusion of this study is that the use of problem solving methods can improve students' mathematics learning outcomes about units of length in class II SD Negeri 5 Panjer for the 2020/2021 academic year.
\end{abstract}

Keywords: Problem Solving Methods, Learning Outcomes, Mathematics

\begin{abstract}
Abstrak
Penelitian ini yaitu untuk: untuk mengetahui penggunaan metode pemecahan masalah dapat meningkatkan hasil belajar Matematika tentang satuan panjang pada kelas II SD Negeri 5 Panjer Tahun Ajaran 2020/2021. Penelitian ini merupakan PTK yang direncanakan dan dilaksanakan oleh peneliti sendiri dalam dua siklus, setiap siklus terdiri dari perencanaan, pelaksanaan, observasi, dan refleksi. Pada siklus I pertemuan I dengan presentase siswa belum tuntas $30,00 \%$ dan tuntas $70,00 \%$. Siklus I pertemuan II yaitu dengan presentase siswa belum tuntas $15,00 \%$ dan tuntas $85 \%$. Siklus II pertemuan I dengan presentase siswa belum tuntas $25,00 \%$ dan tuntas $75,00 \%$. Pada siklus II pertemuan II tetap menggunakan metode pemecahan masalah meningkat dengan presentase siswa belum tuntas $10,00 \%$ dan tuntas $90,00 \%$. Kesimpulan penelitian ini adalah penggunaan metode pemecahan masalah dapat meningkatkan hasil belajar matematika peserta didik tentang satuan panjang di kelas II SD Negeri 5 Panjer tahun ajaran 2020/2021.
\end{abstract}

Kata kunci: Metode Pemecahan Masalah, Hasil Belajar, Matematika 


\section{PENDAHULUAN}

Pendidikan adalah suatu kegiatan yang dilakukan secara sadar dan terencana serta dilakukan dengan penuh tanggung jawab dalam membentuk manusia dengan kecakapan tertentu atau mencapai kedewasaan yang dicita-citakan melalui proses belajar. Tujuan utama dalam pendidikan adalah belajar. Belajar adalah suatu kegiatan untuk memperoleh pengetahuan, memperbaiki perilaku, sikap dan terjadinya perubahan tingkah laku. Pendidikan dasar merupakan proses awal seorang anak mengetahui berbagai macam teknik dalam pembelajaran.

Kurikulum yang saat ini digunakan adalah Kurikulum 2013. Proses pembelajaran pada Kurikulum 2013 menggunakan pembelajaran tematik yang memadukan berbagai konsep atau materi pembelajaran, pembelajaran tematik terpadu juga menghubungkan berbagai keterampilan, sikap, dan nilai pada satu atau lebih mata pelajaran, sehingga dapat memberikan pengalaman bermakna bagi peserta didik. Pembelajaran tematik menekankan pemilihan suatu tema yang sesuai dengan materi pembelajaran untuk menghubungkan berbagai gagasan, konsep, keterampilan, sikap, dan nilai yang terkandung dalam satu atau lebih mata pelajaran. Tema dalam pembelajaran tematik berfungsi sebagai pemersatu atau pengikat informasi yang terkandung dalam satu atau lebih mata pelajaran.

Misalnya dalam pembelajaran matematika peserta didik harus mengetahui berbagai macam teknik membilang, membagi, menambah, dan mengurangi. Dengan mengetahui konsep-konsep tersebut peserta didik mampu belajar di sekolah dengan baik, karena dengan mengetahui konsep dan aplikasinya siswa mampu menyelesaikan masalah sehari-hari baik di sekolah maupun di kehidupan sehari-hari. Pembelajaran matematika tidak hanya berfokus pada ilmu berhitung sehingga proses pembelajarannya tidak dapat dilakukan dengan hapalan, melainkan harus dengan pemahaman. Seorang guru yang mengusai konsep materi pembelajaran dengan baik, jika penyampainnya kepada peserta didik kurang jelas maka terkadang yang diterima menjadi salah. Kemampuan menilai diri sendiri guru sangat penting sebab kekurang aktifan atau ketidakpahaman peserta didik dalam pengajarannya, mungkin dikarenakan faktor guru itu sendiri.

Peserta didik kelas II merasa kesulitan dalam belajar matematika terutama pada soal cerita pada materi satuan panjang. Kesalahan peserta didik adalah lebih mengutamakan penyelesaian tanpa memperhatikan cara mengerjakan yang benar. Dilihat dari kesalahan tersebut peserta didik kelas II belum memahami bagaimana penyelesaian soal cerita dalam materi operasi hitung panjang benda. Guru harus memilih metode maupun media yang sesuai dalam menyampaikan materi operasi hitung terutama pada soal ceita pada kelas II. Pemilihan metode yang kurang tepat bisa dijadikan faktor dalam ketidakmampuan peserta didik dalam penyelesaian soal cerita dalam pembelajaran matematika. Pemecahan masalah merupakan bagian yang tak terpisahkan dalam pembelajaran dalam Matematika dan perlu memperoleh perhatian serius bagi para guru. Penyelesaian masalah bukan hanya sebagai tujuan akhir dari belajar matematika, melainkan bagian terbesar dari aktivitas ini. Dengan menggunakan pemecahan masalah, peserta didik diharapkan dapat mengenal cara berpikir, kebiasaaan untuk tekun, serta percaya diri dalam kegiatan yang tidak biasa. (Turmudi, 2009)

Penelitian ini akan membahas bagaimana penggunaan metode pemecahan masalah dalam meningkatkan kemampuan menyelesaikan soal cerita di kelas II SD Negeri 5 Panjer Kecamatan Kebumen Kabupaten Kebumen. Metode pemecahan masalah yang diteliti adalah metode pembelajaran matematika, agar peserta didik mampu menyelesaiakan permasalahan yang dihadapi dengan mengidentifikasi masalah, mendiagnosis masalah, menemukan langkah-langkah pemecahan dan penyelesaian masalah. Penggunaan metode pemecahan masalah diharapkan dapat membantu peserta didik dalam mengerjakan operasi hitung pada materi satuan 
panjang dalam soal cerita. Karena pembelajaran bervariasi dan lebih menarik, sehingga bisa membantu peserta didik dalam materi satuan panjang

Berdasarkan latar belakang yang telah dipaparkan, maka rumusan masalah dalam penelitian ini adalah : "Apakah penggunaan metode pemecahan masalah dapat meningkatkan hasil belajar matematika peserta didik tentang satuan panjang di kelas II SD Negeri 5 Panjer tahun ajaran 2020/2021?".

Secara umum tujuan penelitian tindakan kelas ini bertujuan untuk mengetahui apakah penggunaan metode pemecahan masalah dapat meningkatkan hasil belajar Matematika tentang satuan panjang pada kelas II SD Negeri 5 Panjer Tahun Ajaran 2020/2021.

\section{METODE}

Penelitian Tindakan Kelas ini dilaksanakan di SD Negeri 5 Panjer dari bulan Desember hingga bulan Juli 2021. Subjek penelitian ini adalah peserta didik kelas II tahun ajaran 2020/2021 yang berjumlah 20 terdiri dari 12 laki-laki dan 8 perempuan.

Prosedur yang akan digunakan dalam penelitian ini menggunakan penelitian dari Arikunto (2007) yang meliputi empat tahapan yaitu perencanaa, pelaksanaan tindakan, observasi dan refleksi. Penelitian ini terdiri dari dua siklus yang masing-masing dua pertemuan.

Teknik pengumpulan data dengan observasi, tes dan dokumen.. Observasi langsung dilakukan pada guru dan siswa kelas II SD Negeri 5 Panjer Kecamatan Kebumen Kabupaten Kebumen, untuk mengetahui pemahaman konsep satuan panjang pada saat pembelajaran berlangsung. Alat yang digunakan dalam observasi ini beruba lembar observasi kinerja guru dan juga lembar observasi aktifitas siswa. Teknik pengumpulan data berikutnya adalah dengan menggunakan tes untuk mengetahui pemahaman konsep satuan panjang pada siswa kelas II SD Negeri 5 Panjer Kecamatan Kebumen Kabupaten Kebumen menggunakan metode pemecahan masalah. Tes yang diberikan yaitu tes tertulis mengenai satuan panjang. Tes atau evaluasi dilaksanakan pada akhir pembelajaran setiap siklus. Dokumen yang dikaji dalam penelitian ini adalah arsip atau dokumen yang ada. Indikator kinerja penelitian ini adalah penerapan metode pemecahan masalah dan peningkatan hasil belajar Matematika satuan panjang.

\section{HASIL DAN PEMBAHASAN}

Perbandingan hasil tindakan antarsiklus dilakukan untuk mendeskripsikan adanya peningkatan hasil tindakan dari satu siklus ke siklus berikutnya. Pelaksanaan penelitian dilakukan selama dua siklus, setiap siklus dilaksanakan 2 kali pertemuan dengan materi yang berbeda. Selama pelaksanaan menerapkan metode pemecahan masalah yang merupakan suatu upaya dalam meningkatkan hasil belajar Matematika tentang satuan panjang.. Dari pelaksanaan tindakan siklus I, dan II, hasil belajar Matematika tentang satuan panjang.

Proses pembelajaran dilaksanakan dengan langkah sebagai berikut: (1) penjelassan materi dari guru; (2) pembagian LKPD pada peserta didik; (3) peserta didik mengerjakan soal yang berhubungan dengan satuan panjang; (4) peserta didik memecahkan masalah sehari-hari tentang satuan panjang; (5) peserta didik bertanya jawab tentang apa yang diketahui dan ditanyakan dari masalah yang disediakan; (6) peserta didik menyajikan penyelesaian masalah sehari-hari tentang panjang (7) presentasi kelompok; (8) refleksi dan penarikan kesimpulan.

Hasil observasi penerapan metode pemecahan masalah menunjukkan peningkatan di setiap siklusnya hingga mencapai kinerja penelitian yang ditargetkan. 
Tabel 1. Presentase Hasil Observasi Guru dan Peserta Didik

\begin{tabular}{ccccc}
\hline \multirow{2}{*}{ Keterangan } & \multicolumn{4}{c}{ Nilai hasi observasi } \\
& Pertemuan & Pertemuan & Pertemuan & Pertemuan \\
& I & II & I & II \\
\hline Guru & 3,73 & 3,80 & 3,80 & 3,86 \\
Peserta didik & 3,60 & 3,67 & 3,86 & 3,86 \\
\hline
\end{tabular}

Berdasarkan tabel 1, diketahui bahwa rata-rata hasil observasi guru pada siklus I yaitu 3,76. Pada siklus II mengalami peningkatan menjadi 3,83. Sedangkan untuk ratarata hasil observasi peserta didik pada siklus I yaitu 3,63. Pada siklus II mengalami peningkatan menjadi 3,86.

Pengamatan hasil belajar yang dilakukan dengan evaluasi di akhir pembelajaran untuk mengetahui kemampuan siswa setelah mengikuti pembelajaran. Analisis hasil digunakan untuk membandingkan hasil evaluasi pada siklus I, dan II. Berikut tabel analisis nilai hasil belajar siklus I, dan II.

Tabel 2. Presentase Hasil Belajar Peserta Didik

\begin{tabular}{ccccc}
\hline \multirow{2}{*}{ Keterangan } & \multicolumn{4}{c}{ Persentase Siklus (\%) } \\
& Pertemuan & Pertemuan & Pertemuan & Pertemuan \\
& I & II & I & II \\
\hline Tuntas & 70,00 & 85,00 & 75,00 & 90,00 \\
Belum Tuntas & 30,00 & 15,00 & 25,00 & 10,00 \\
\hline
\end{tabular}

Berdasarkan tabel 2. diketahui nilai rata-rata hasil belajar dalam setiap siklusnya mengalami peningkatan. Nilai rata-rata hasil belajar pada siklus I pertemuan I dengan siswa yang tuntas $70,00 \%$. Pada siklus I pertemuan II dengan persentase siswa tuntas $85,00 \%$. Pada siklus II pertemuan I dengan persentase siswa yang tuntas $85,00 \%$ dan siklus II pertemuan II mengalami peningkatan dengan persentase siswa tuntas 90,00\%. Dari data tersebut dapat disimpulkan nilai rata-rata hasil belajar pada siklus I, dan II, secara keseluruhan sudah baik dan mengalami peningkatan pada tiap siklusnya.

Berdasarkan hasil observasi langkah pembelajaran dengan metode pemecahan masalah berhasil diterapkan dan peserta didik dapat mengikuti pembelajaran dengan baik. Meski demikian, selama proses pembelajaran ditemukan beberapa kendala. Kendala tersebut antara lain: (1) kendala sinyal dalam pembelajaran guru (2) peserta didik belum percaya diri mengajukan pertanyaan; (3) terdapat sebagian peserta didik yang belum melakukan langkah yang tepatdalam memecahkan masalah; (4) peserta didik belum percaya diri dalam ketika melakukan kegiatan presentasi. Adapun solusi dari kendala tersebut antara lain: (1) mencari lokasi dengan sinyal yang baik dan guru mengubah penjelasan melalui WAG (WhatsApp Group) (2) guru memberikan dorongan dan motivasi agar lebih percaya diri; (3) guru memberikan arahan langkah-langkah yang tepat dalam memecahkan masalah, (4) guru memotivasi peserta didik supaya tidak malu untuk melakukan pesentasi kelompok.

Berdasarkan penelitian yang telah dilakukan dapat diketahui salah satu upaya untuk meningkatkan pembelajaran matematika tentang ukuran panjang di kelas II adalah dengan menggunakan metode pemecahan masalah karena dapat mengembangkan kemampuan siswa dalam menyelesaikan masalah-masalah, membuat siswa aktif belajar, memberikan pengalaman nyata kepada siswa tentang ukuran panjang serta mengembangkan ketrampilan berhitung dalam kehidupan seharihari. 
Dengan demikian penerapan metode pemecahan masalah dapat meningkatkan pemecahan maslaah dalam yang dilihat dari ketercapaian dari siklus I hingga siklus II. Hasil penelitian ini memperkuat penelitian yang dilakukan oleh Fata Saifudin (2016) yang menyatakan bahwa penggunaan metode problem solving dapat paya meningkatkan kemampuan pemecahan masalah Matematika.

\section{SIMPULAN}

Berdasarkan rumusan masalah, kajian teori, metode penelitian, hasil penelitian, dan pembahasan dalam penelitian ini, dapat diambil kesimpulan sebagai berikut: bahwa Penggunaan Metode Pemecahan Masalah dapat meningkatkan Hasil Belajar Matematika Peserta Didik tentang Satuan Panjang di Kelas II SD Negeri 5 Panjer tahun ajaran 2020/2021.

Berdasarkan hasil penelitian, pembahasan, serta kesimpulan dalam penelitian ini, dapat disampaikan saran-saran sebagai berikut: (1) bagi peserta didik, hendaknya meningkatkan keberanian dalam mengungkapkan pertanyaan yang disampaikan baik oleh guru maupun peserta didik yang yang lain. Peserta didik sebaiknya lebih memperhatikan cara penyelesaian dalam soal cerita sehingga dalam pembelajaran lebih paham tentang masalah ataupun pemecahan masalah yang harus dilakukan, (2) bagi guru, hendaknya memberikan pengalaman mengenai penggunaan metode pembelajaran secara tepat, sehingga dapat digunakan untuk pembelajaran pada subtema maupun tema lain, (3) bagi sekolah, hendaknya sekolah mengupayakan sosialisasi atau pelatihan bagi guru mengenai metode-metode pembelajaran yang inovatif yang dapat meningkatkan wawasan mengenai masalah-masalah yang dialami oleh siswa serta upaya peningkatan kualitas kegiatan pembelajaran di sekolah agar lebih efektif dan efesien. Dan (4) bagi peneliti, hendaknya membuat suatu kegiatan yang lebih menarik, inovatif, dan kreatif yang sesuai dengan perkembangan ilmu, teknologi, dan zaman.

\section{DAFTAR PUSTAKA}

Abdurahman, M. (2003). Pendidikan Bagi Anak Berkesulitan Belajar. Jakarta : Rineka Karya.

Arikunto, Suharsimi. 2013. Prosedur Penelitian, Suatu Pendekatan Praktis. Jakarta : Rineka Cipta

Desmita. (2009). Psikologi Perkembangan Peserta Didik. Bandung: Rosdakarya.

Muhsetyo, G. (2011). Pembelajaran Matematika di SD. Jakarta : Universitas Terbuka.

Prayitno. 2005. Dasar Teori dan Praksis Pendidikan. Jakarta : Grasindo

Susanto, Ahmad. 2013. Teori Belajar dan Pembelajaran di Sekolah Dasar. Jakarta: Prenadamedia Grup

Turmudi. (2009). Landasan dan Filsafat Teori Pembelajaran Matermatika Berparadigma Eksploratif dan Investigatif. Jakarta : Leuser Cita Pustaka.

Wahyudi.2008. Pembelajaran Matematika di Sekolah Dasar. Surakarta: UNS 